\title{
The Effect of Teaching Materials Based on Aceh's Local Wisdom on Student Learning Results of Junior High School in Aceh Province
}

\author{
Mardhatillah ${ }^{1}$, Verawati $^{1}$, Evi Eviyanti $^{2}$, Isda Pramuniati ${ }^{2}$ \\ ${ }^{1}$ STKIP Bina Bangsa Meulaboh, Indonesia \\ ${ }^{2}$ Universitas Negeri Medan, Indonesia \\ Email: mardhatillah.atjeh@gmail.com
}

\begin{abstract}
:
This study aims to determine the effect of teaching materials based on local Aceh's wisdom on student learning outcomes in learning English in class VII SMP Aceh Besar. This study uses a quasiexperimental method, consisting of a control class and an experimental class. Data collection techniques using written tests. Technical data analysis with $t$-test. The results showed that the value of $t_{\text {count }}=2.664$ was obtained. At the significant level $a=0.05$ and $d k=35+35-2=68$, the price of $t_{\text {table }}=1.669$ (complete calculation in attachment 21 ) is obtained. By comparing $t_{\text {count }}$ and $t_{\text {table }}$ obtained $t_{\text {count }}>t_{\text {table }}$ or $2.664>1.669$ means that $H_{a}$ is accepted and $H_{0}$ is rejected. This shows that Aceh's local wisdom-based teaching materials are effective in improving student learning outcomes in $7^{\text {th }}$ grade of Aceh Besar Junior High School.
\end{abstract}

Keywords :

teaching materials; student learning outcomes; junior high school; Aceh province

\section{Introduction}

Education and learning in various fields of science in schools today seem arid (dry) from the beauty of life, stuffed with memorization of theory and very minimal practice, too abstract, and less touches on the values and dimensions of humanity from the field of science being taught. Education and learning should be an integral part of human culture and therefore have humanistic characteristics. (Sinaga,2016)

Teaching materials used by English teachers in Aceh Besar so far have several weaknesses. Among these teaching materials have not been able to introduce the wealth of the region in the student environment to students. Different learning needs are based on geographical, ethnographic, and regional wealth characteristics. Good teaching materials are those that are developed in accordance with the needs of its users, namely needs which are based on geographical, ethnographic factors, and regional wealth characteristics. (Mardhatillah, et al., 2019) (Yee et al., 2015) (Ramos, Dolipas, \& Villamor, 2013).

The adoption of a new paradigm in the form of teaching and learning materials adopted from outside and adapted in schools, requires students and teachers to change their teaching and learning behavior. Constructive interactions between students and their peers, students and teachers, student-teacher problems are very difficult to condition (Anzar \& Mardhatillah, 2017). This is due to conventional teaching which conditions students to be passive in receiving knowledge. During this time, the teacher gives the concepts and principles of English in the form of "whole" to students, and not accustoms students to connect English in solving problems and thinking creatively.

According to the National Center for Vocational Education Research Ltd. / National Center for Competency Based Training, teaching materials are all forms of material used to assist 
teachers / instructors in carrying out teaching and learning activities in class. The types of teaching materials include:

a. Visual teaching materials consist of printed materials such as handouts, books, modules, student worksheets, brochures, leaflets, wall charts, photos / drawings, and non-printed (non-printed), such as models / mockups.

b. Learning materials (audio) such as cassettes, radios, vinyl records, and audio compact disks.

c. Teaching and listening materials (audio visual) such as compact disk videos, films.

d. Interactive multimedia teaching materials (interactive teaching material) such as CAI (Computer Assisted Instruction), interactive learning multimedia compact disk (CD), and web-based teaching materials (web-based learning materials). (Nugraha, Binadja, \& Supartomo,2015)

Teaching materials provide instructional guidance for educators that will enable them to teach without having to look at the syllabus because the teaching materials have been designed in accordance with the syllabus and curriculum. In this case, it is certain that teaching materials will stimulate the learning process to run in accordance with the existing learning objectives. The development of teaching materials must be based on prerequisites from the competent body namely the National Education Standards Agency (BSNP), and the applicable curriculum.

The development of teaching materials/learning media in English is motivated by different theories, so as to produce a form of teaching material/learning media that is applied to the principles of learning. Learning development model serves to direct us to design learning that is used as a guide in the implementation in order to achieve effective, efficient and efficient learning.

Another form of innovation in the development of English teaching materials is the use of scientific approaches in learning. The learning process will not motivate students if the delivery uses an inappropriate approach. The role of educators in determining learning methods in the classroom is not determined by what will be learned, but rather how the presentation of material and how to complete complex and abstract concepts will enrich students' learning experiences. The most common learning method used by teachers is lectures. Though the method is not very suitable for the delivery of certain materials, as a result students lack understanding of the subject matter. Teaching materials developed are expected to improve the English language proficiency of students High School Junior in Aceh Besar, and can solve problems in learning in class so far.

Teaching Material Based on Local Wisdom of Aceh Besar embraces learning theories and learning that embraces constructivism (especially social constructivist theory), top-down learning (students begin by solving complex problems by solving simpler parts of problems and discovering basic skills necessary so that the whole problem is solved). Application of the characteristics of these teaching materials by involving the four aspects of the culture of Aceh Besar in each of the components and in the implementation of the learning process through teaching materials in class.

Innovation of teaching materials cannot be separated from attention to instructional materials or instructional materials, namely knowledge, skills, and attitudes that students must learn in order to achieve predetermined competency standards.

The use of appropriate teaching materials will have an impact on the success of student learning in class (Trisdania, 2018). In addition, innovative teaching materials can create meaningful learning so as to create good quality learning. (Nugraha et al., 2015). Local culture-based teaching 
materials are able to foster the character of students' cultural love (Laksana, Kurniawan, \& Niftalia, 2016).

\section{Research Method}

The method used in this study is an experimental questionnaire method, which is research that is intended to determine whether there is an influence of something imposed on the subject, in this case the seventh grade students of junior high school. This study uses two classes, namely the experimental class and the control class.

The research design is presented in the following table:

Table 1. Research Design

\begin{tabular}{|c|c|c|c|}
\hline School & Pretest & Treatment & Post Test \\
\hline Experiment & T1 & $\mathrm{X}$ & T2 \\
\hline Control & T1 & Y & T2 \\
\hline
\end{tabular}

Information:

T1 : Preliminary test

T2 : Final Test

$\mathrm{X} \quad$ : Learning through teaching materials based on local Acehnese wisdom

Y : Learning with conventional teaching materials

This research was conducted in second semester of $7^{\text {th }}$ grade Junior High School Aceh Besar, in February until August 2018. This study was scheduled for 4 meetings for each sample class.

\subsection{Data analysis technique}

\section{- Student learning outcomes}

Student learning outcomes obtained through scoring without correction of guess answers on the objective test are one for the correct answer.

$$
\text { Score }=\frac{\text { Number of correct answer items }}{\text { Total number of items }} x 100
$$

Based on school policy the criteria for determining the level of student mastery of subject matter are taught using guidelines in the form of KKM. This means that students are considered to have finished learning English if the learning outcomes reach KKM in English for a class of 60.

While classically the average value of students is calculated based on the value of each individual by:

$$
\text { Average }=\frac{\sum \text { The total score of all students }}{\sum \text { All student }} \times 100
$$

While the mastery of learning outcomes in English is classically determined by the number of students who are complete in learning. 


$$
P=\frac{\sum \text { Students who have finished learning }}{\sum \text { Student }} \times 100 \%
$$

So that English learning successfully provides classical completeness when there are at least $85 \%$ of students who have achieved the KKM grade.

\section{- Effectiveness of interactive teaching materials on Student Learning Outcomes.}

The effectiveness of interactive teaching materials on student learning outcomes after learning is identified using normal gain as follows:

$$
\text { Ngain }=\frac{\text { score postest }- \text { score pretest }}{\text { score ideal }- \text { score pretest }} \times 100
$$

For class-sized samples, the intended score is the average score. An interpretation of the effectiveness of the $N$ gain calculation is given the following table:

Table 2. Interpretation of Effectiveness of N Gain

\begin{tabular}{|c|c|}
\hline Percentage $(\%)$ & Interpretation \\
\hline$<40$ & Uneffective \\
\hline $40-55$ & Less effective \\
\hline $56-75$ & Effective enough \\
\hline$>76$ & Effective \\
\hline
\end{tabular}

Hypothesis Formulation

Hypothesis:

$\begin{array}{ll}\text { Ho } & : \mu \mathrm{A} 1 \leq \mu \mathrm{A} 2 \\ \mathrm{Ha} & : \mu \mathrm{A} 1>\mu \mathrm{A} 2 \\ \mu \mathrm{A} 1 & : \text { Average student learning outcomes with interactive teaching materials } \\ \mu \mathrm{A} 2 & : \text { Average student learning outcomes with ordinary teaching materials }\end{array}$

\section{Result and Discussion}

\subsection{Calculation of Effectiveness of Interactive Teaching Material based on Local Wisdom}

The effectiveness of the teaching materials tested in the experimental and a control class was calculated using the percentage gain of $\mathrm{N}$ gain with its interpretation. The results of the calculation of $\mathrm{N}$ gain for all sample classes in each school can be seen in the following Table:

Table 3. Calculation of $\mathrm{N}$ gain for each sample class

\begin{tabular}{llllll}
\hline \multirow{2}{*}{ Class } & Postest & Pretest & Ideal & \multirow{2}{*}{ N gain } & Conclussion \\
& Average & Average & Score & & \\
Control & 65,5 & 22,9 & 100,0 & $55 \%$ & Less effective \\
Experiment & 72,8 & 27,9 & 100,0 & $62 \%$ & Effective enough \\
\hline
\end{tabular}

Teaching materials have an effective effect on improving student learning outcomes in English. While teaching materials in the form of textbooks tested in the control class get an 
effectiveness of $55 \%$, this means that teaching materials in the form of textbooks that are tested have less effective effect on improving student learning outcomes in English. It can be concluded that the interactive English teaching material based on Aceh's local wisdom developed has an influence on students' English learning outcomes. Based on the above table, the interactive English teaching material based on Aceh's local wisdom tested in the experimental class gained $62 \%$ effectiveness.

\subsection{Data Normality Test}

Data normality testing is done by using Liliefors test. Before testing the hypothesis, the data from the research results must meet several requirements that must be met, namely data normality. From the test results obtained as shown in the table as follows:

Table 4. Summary of Data Normality

\begin{tabular}{llrrl}
\hline Control & Data & $\mathrm{L}_{\text {tabel }}$ & $\mathrm{L}_{\text {hitung }}$ & Information \\
Class & Postest & 0,1498 & 0,1201 & Normal \\
& Pretest & 0,1498 & 0,1065 & Normal \\
\multirow{2}{*}{ Experiment } & Postest & 0,1498 & 0,1123 & Normal \\
& Pretest & 0,1498 & 0,1398 & Normal \\
\hline
\end{tabular}

The table above explains that $\mathrm{L}_{\text {count }}<\mathrm{L}_{\text {table }}$ so that a conclusion can be drawn that the population data is normally distributed from the two classes.

\section{3. Data Homogeneity Test}

The results of calculations for the pretest and posttest data from the two class groups (experimental and control classes) in the following table:

Table 5. Summary of Data Homogeneity

\begin{tabular}{llrrrr}
\hline Data & Class & Variance & $\mathrm{F}_{\text {tabel }}$ & $\mathrm{F}_{\text {hitung }}$ & Infomation \\
\multirow{2}{*}{ Pretest } & Control & 152,36 & 1,76 & 1,23 & Homogen \\
& Experiment & 124,21 & & & \\
\multirow{2}{*}{ Postest } & Control & 124,19 & \multirow{2}{*}{1,76} & 1,04 & Homogen \\
& Experiment & 129,04 & & & \\
\hline
\end{tabular}

Based on the table above the value of $\mathrm{F}_{\text {count }}<\mathrm{F}_{\text {table }}$ which means that the sample used in this study is stated to be a homogeneous population variance.

Homogeneity test data is carried out aiming to get whether the samples taken are homogeneous or not, meaning whether the samples taken can represent the entire population. Homogeneity test data is done by the F test.

The results obtained about the initial ability of students before being given treatment concluded that there was no significant difference between the initial abilities of students before being given a different treatment, obtained $\mathrm{t}_{\text {count }}=0.175$. At the significance level $\alpha=0.05$ and $\mathrm{dk}$ $=35+35-2=68$, the price of $t_{\text {table }}=1.997$ is obtained. By comparing $t_{\text {count }}$ and $t_{\text {table }}$ obtained $t_{\text {count }}$ $<\mathrm{t}_{\text {table }}$ or $0.175<1.997$ so that $\mathrm{H}_{\mathrm{o}}$ is accepted or $\mathrm{H}_{\mathrm{a}}$ is rejected.

Next test the value of the posttest by using the t-test that distinguishes the average posttest of the experimental class students and the control class with the aim to get the presence or absence of differences in influence between the use of English interactive teaching materials based on 
Aceh's local wisdom with ordinary textbooks on student learning outcomes, it was concluded that there was a significant difference in effect between the use of interactive English teaching materials based on Aceh's local wisdom and conventional learning on English learning outcomes in $1^{\text {st }}$ grade of Junior High School in Aceh Besar. Hypothesis testing results obtained $t_{\text {count }}=2.664$. At the significant level $\alpha=0.05$ and $\mathrm{dk}=35+35-2=68$, the price of $\mathrm{t}_{\text {table }}=1.669$ (complete calculation in attachment 21) is obtained. By comparing $t_{\text {count }}$ and $t_{\text {table }}$ obtained $t_{\text {count }}>t_{\text {table }}$ or 2.664>1.669 means that $\mathrm{H}_{a}$ is accepted and $\mathrm{H}_{0}$ is rejected.

Table 6. t-test Calculations

\begin{tabular}{lllllll}
\hline Data & Class & Average & & $\mathrm{t}_{\text {tabel }}$ & $\mathrm{t}_{\text {hitung }}$ & Descriptiom \\
\multirow{2}{*}{ Postest } & Control & 65,5 & 1,6 & 2,6 & There are differences in \\
& & & 64 & 64 & initial abilities \\
\multirow{2}{*}{ Pretest } & Experiment & 72,8 & 1,9 & 0,1 & There are similarities in \\
& Control & 22,9 & 1,9 & 75 & initial abilities \\
\cline { 2 - 6 }
\end{tabular}

\subsection{Discussion}

Learning by using interactive English teaching materials based on Aceh's local wisdom makes students more active in exploring existing abilities; students are invited to connect the stamp duty with students' daily experiences and social environment.

Learning objectives (learning Objectives or performance objectives) are a guide for making an instructional design and making exercises / tests to measure students' ability to absorb learning material. Unclear learning goals not only result in programs becoming wordy or unfocused in explaining the material, but also result in behavior or performance that is expected to be mastered by the user not achieved. Students and teachers can benefit from learning with interactive teaching materials. Some of them are the flexibility of learning activities, both in terms of student interaction with learning material, as well as student and teacher interaction, as well as interaction between fellow students to discuss learning material.

Interactive English teaching materials based on Aceh's local wisdom used in the experimental class get an effectiveness score of $62 \%$, which means that it is quite effective in improving student learning outcomes in English. Unlike the case with ordinary textbooks used in conversational classes get an effectiveness of $55 \%$ which means teaching materials in the form of ordinary textbooks have less effective effect in improving student learning outcomes in learning English.

Teachers are required to develop themselves in teaching which seems to be still underdeveloped in educators today. The impact of this lack of self-development is that many educators are unable to organize interesting and fun learning. This situation is one of them is inseparable from the lack of development of innovative teaching materials (Ariyani \& Wangit, 2016) the ability of teachers in developing teaching materials is able to create effective and meaningful learning (Hanum \& Rahmadona, 2009).

The Greater Aceh region is mainly agricultural, plantation and fisheries. So that the source of community livelihood is agriculture, plantation and fisheries. Concrete objects and demands of the world of work in them can be used as inspiration in the formulation of the required English competence. 
Competence can be defined as a combination of skills, abilities, and knowledge needed to complete a particular task. In Kepmendiknas (The decision of the minister of national education )No.045 / U / 2002, competency is defined as a set of smart, responsible full actions that a person has as a condition to be deemed capable by the community in carrying out tasks in certain fields of work. The Australian National Training Authority (ANTA) defines competencies as follows:

The concept of competency focuses on what is expected of an employee in workplace rather than the learning process, and embodies the ability to transfer and apply skills and knowledge to new situations and environments.

Based on the above definition, competence can be interpreted how much the chances of a graduate obtaining / completing a particular job compared to the process / learning time and how much the opportunity to realize the ability to apply and apply the knowledge and skills possessed in a new situation and environment. Evidence of the success of learning English in schools, how much the contribution of knowledge and transferability of English language possessed by graduates to answer the problems of life in society in general and specifically in the cultural environment. The thing that can be done by an educational institution (school) in learning English is to raise issues originating from facts and cultural environment in the area where students are located, through the formulation of basic competencies and indicators of English competence for a learning program conducted. . Standards can be defined as something that is set and established (by the authorities) to measure quality. Competency standards must reflect established quality standards for graduates. The competencies are further described in the elements of competency or basic competencies set for a particular subject (English).

The purpose of making teaching material that is must be in accordance with student needs, characteristics and the environment around students. The material in the book is in accordance with the characteristics and conditions around students. This suitability is needed so that students can more easily understand and become familiar with the conditions around them (Febrianti Yuli Sastriani, 2017).

Meaningful learning can be obtained if children learn in accordance with their social environment. So that cultural elements cannot be released in designing learning in school. In addition, in the 2013 curriculum framework it is also mentioned that in compiling and developing learning activities must pay attention to the principles of preparation and development in accordance with the conditions in the education unit both the initial ability of students, interests, learning motivation, talents, potential, social abilities, emotions, learning style, special needs, speed of learning, cultural background, norms, values, and / or the environment of students (Ministry of Education and Culture, (Laksana et al., 2016)

The development of teaching materials based on local culture needs to be done by meeting scientific development standards. The development of learning activities based on local cultural values make a positive contribution to increasing competency-based student literacy. Integration of local cultural values in curriculum development such as setting learning goals, designing learning materials, determining learning strategies, learning media, and evaluating learning are important for quality of learning (Zulela, 2016).

\section{Conclusion}

Based on the results of the previous analysis, it can be concluded that teaching materials based on local Aceh wisdom can improve student learning outcomes in $7^{\text {th }}$ grade of Senior high school in Aceh Besar. Aceh's local wisdom-based teaching materials are expected to be used and 
developed by other researchers with other cultures to support the strengthening of diversity in the Unitary State of the Republic of Indonesia.

\section{References}

Anzar, S. F., \& Mardhatillah. (2017). Analisis Kesulitan Belajar Siswa Pada Pembelajaran Bahasa Indonesia Di Kelas V Sd Negeri 20 Meulaboh Kabupaten Aceh Barat Tabun Ajaran 2015 / 2016. 4(1), 5364.

Ariyani, Y. D., \& Wangit, M. N. (2016). Pengembangan Bahan Ajar Tematik-Integratif Berbasis Nilai Karakter Peduli Lingkungan Dan Tanggung Jawab. Jurnal Pendidikan Karakter, 6(1), 116-129.

Febrianti Yuli Sastriani. (2017). Pengembangan Buku Guru Dan Siswa Berbasis Multiple Intelligences, Joyfull Learning Dan Keunggulan Lokal Pada Kelas Iv Tema Daerah Tempat Tinggalku. 1, 1-11.

Hanum, F., \& Rahmadona, S. (2009). Implementasi Model Pembelajaran Multikultural di Sekolah Dasar di Propinsi Daerah Istimewa Yogyakarta. In Artikel Multikultural-Stranas 2009. https://doi.org/10.21831/JPIPFIP.V0I0.4629

Laksana, D. N. L., Kurniawan, P. A. W., \& Niftalia, I. (2016). Pengembangan Bahan Ajar Tematik Sd Kelas Iv Berbasis Kearifan. 3(1), 1-10. https://doi.org/0000-0003-4695-5403

Mardhatillah, Mardhatillah, Verawati, Eviyanti, E., Pramuniati, I., \& Ramadhani, F. (2019). Teaching Materials Based on Local Wisdom to Create Meaningful Learning in Aceh Province. 208(Icssis 2018), 101-105. https://doi.org/10.2991/icssis-18.2019.20

Mardhatillah, Verawati, Eviyanti, E., \& Pramuniati, I. (2019). Bahan Ajar Interaktif Berbasis Kearifan Lokal. Genta Mulia, X(1), 38-53.

Nugraha, D. A., Binadja, A., \& Supartomo. (2015). Pengembangan Bahan Ajar Reaksi Redoks Bervisi SETS, Berorientasi Konstruktivistik. Journal of Innovative Science Education (JISE), 2(1), 27-34. Retrieved from http://journal.unnes.ac.id/sju/index.php/jise

Ramos, J. L. S., Dolipas, B. B., \& Villamor, B. B. (2013). Higher Order Thinking Skills and Academic Performance in Physics of College Students: A Regression Analysis. Bulletin of the Museum Society of Maidugur.

Sinaga, B. (2016). Inovasi Model Pembelajaran Berbasis Budaya Batak. Generasi Kampus, 7(2), 187_ 208. Retrieved from http://mynewtpsl.blogspot.com/2016/07/vbehaviorurldefaultvmlo.html

Trisdania, E. (2018). Pengembangan Media Pembelajaran Berbasis Macromedia Flash untuk Meningkatkan Kemampuan. 5(1).

Yee, M. H., Yunos, J. M., Othman, W., Hassan, R., Tee, T. K., \& Mohamad, M. M. (2015). Disparity of Learning Styles and Higher Order Thinking Skills among Technical Students. Procedia - Social and Behavioral Sciences. https://doi.org/10.1016/j.sbspro.2015.08.127

Zulela. (2016). Pendekatan Kontekstual Dalam Pembelajaran Menulis Di Sekolah Dasar (Action Research di Kelas Tinggi Sekolah Dasar). Mimbar Sekolah Dasar, 1(1). https://doi.org/10.17509/mimbar-sd.v1i1.1363 